\title{
TECHNO-RESONANCE INNOVATION CAPABILITY FOR ENHANCING MARKETING PERFORMANCE: A PERSPECTIVE OF RA-THEORY
}

\author{
Lauw Sun HIONG(1) ${ }^{1,2}$, Augusty Tae FERDINAND ${ }^{3^{*}}$, Erna LISTIANA ${ }^{4}$ \\ ${ }^{1}$ Department of Management, Tanjungpura University, Pontianak, Indonesia \\ ${ }^{2}$ Faculty of Economics and Business, Widya Dharma University, Pontianak, Indonesia \\ ${ }^{3}$ Department of Management, Diponegoro University, Semarang, Indonesia \\ ${ }^{4}$ Department of Management, Tanjungpura University, Pontianak, Indonesia
}

Received 15 February 2020; accepted 23 March 2020

\begin{abstract}
The current study is conducted to fill up the research gap on the inconsistent findings of the ability of market orientation in enhancing marketing performance through inserting the techno-resonance innovation capability and product innovativeness as factors to leverage marketing performance. Five hypotheses were developed and tested in a sample frame of 121 SMEs in the region of West Borneo, Indonesia. The findings of this study demonstrate the pivotal role of technoresonance innovation capability in two folds. Firstly, a techno-resonance innovation capability is proved as a mediator of marketing orientation in enhancing marketing performance. Secondly, the techno-resonance innovation capability, which holds the potential for enhancing the product innovativeness, is essential but not sufficient to enhance marketing performance; still, another extra effort is necessary, such as resonating the value of innovativeness to the target market.
\end{abstract}

Keywords: market orientation, techno-resonance innovation capability, product innovativeness, market performance, Indonesia.

JEL Classification: M13, M310, O32.

\section{Background to the research}

The market environment changes rapidly due to many factors such as innovation in technology and its related derivations in products and services. A company that focuses its attention on understanding the dynamics in the marketplace will maintain a close relationship with its consumers as well as its competitors known as market-oriented companies will be better performing in the marketplace. The company's ability to understand and collect information from consumers as well as competitors is a strategic asset to facing the challenges of competition (Cheng \& Huizingh, 2014; Long et al., 2017; Mahrous \& Genedy, 2019). A market-oriented strategy is also recognized as a critical success factor to win the competition (Cheng \& Huizingh, 2014; Kaliappen \& Hilman, 2017). Those above studies rooted on the seminal work of Kohli and Jaworski (1990) and Narver and Slater (1990) who introduced the concept of market orientation as an organizational culture that energizing marketing division or organization to be more focus on it consumer's need, aware of its competitor's maneuvers, collecting of relevant pieces of information concerning consumers and competitor, coordinating and disseminating information or market intelligence across departments and energizing organization-wide responsiveness to the marketplace. Previous studies of marketing scholars proved the significant role of market orientation in enhancing the marketing performance (Cacciolatti \& Lee, 2016; Fernandes et al., 2020; Lee et al., 2015; Long et al., 2017). However, several studies come out with opposite results, such as research on SMEs in India shows the insignificant effect of consumer orientation (a dimension of market orientation) to marketing performance (Yadav, Tripathi, \& Goel, 2019). The study of Sun et al. (2016) provides findings of no impact of market-orientated strategy on performance. Study of Kocak, Carsrud, and Oflazoglu (2017) on the Turkish SMEs demonstrated the same result of the no-significant impact of responsive market orientation to performance, Study of Mandhachitara and Allapach (2017) in Thailand SMEs resulted in the non-significant influence of market orientation to performance. This inconsistent finding on the capability of market orientation to marketing performance leads us to raise a research problem on "what process should be developed to facilitate market orientation to be capable in enhancing marketing performance, as discussed in the following passage.

${ }^{*}$ Corresponding author. E-mail: augusty@live.undip.ac.id 
Considering the inconsistent findings of the impact of marConsidering the inconsistent findings of the impact of market orientation on marketing performance, the current study is directed to solve this research gap by adopting the Resource Advantage Theory of competition perspective- abbreviated as R-A Theory. The reason for the adoption of the R-A Theory is the R-A theory emphasizing the vital role of management to acquire, develop and utilize the heterogeneous firm resources to be advantageous in enhancing performance, particularly in the competitive market. The inspiring two foundational premises of the R-A theory is; first, management's role is to configure strategy, based on the advantages of resources they build and cultivate within the historical life of a company and second, competitive dynamics should be understood as a disequilibrium-provoking strategy through innovation strategy as well as innovation resources (Hunt, 2001; Hunt \& Morgan, 1997). These premises lead us to propose the concept of techno-resonance innovation capability for mediating the role of market orientation to enhance marketing performance. Therefore, the current research is aimed at bridging the research gap in the literature by developing a conceptual model comprising the concept of market orientation, techno-resonance innovation capability, product innovativeness, and marketing performance. At the practical level, two 2018 surveys reported two main barriers to SME's growth in Indonesia are the Financial and Marketing aspect of doing business (Asia Pacific Foundation of Canada, 2018, p. 15). An OECD 2018 country review report highlights the recognition of SMEs by the Indonesian government recognizes SMEs as the key drivers of economic growth, through increasing the innovation activity in SMEs. In the spirit of enhancing marketing performance through innovation capability (OECD, 2018) as detailed in our model, we chose the SMEs in Indonesia for testing our research model.

\section{Literature review and hypothesis development}

\subsection{Techno-resonance innovation capability in the framework of RA theory}

Innovation capability has attracted so many marketing scholars in analyzing the potential impact of this type of capability in business as well as in the marketing science, both for big companies and small-medium enterprises. Studies indicated that innovation capability is leveraged by so many factors, among others, tacit knowledge transfer, market orientation, intellectual resources, and strategic \& leadership in innovation (Samson, Gloet, \& Singh, 2017). Studies also demonstrated the impact of innovation capability such as its power to enhance product uniqueness for attracting customer as well as consumer in terms of the value of excitement (Etkin, 2016) as a result of innovation, positive impact on company reputation as a means for attracting and retaining customers (Foroudi et al., 2016), positive impact on innovation performance as well as business performance (Samson et al., 2017). The R-A theory recognizes the innovation capability as a kind of company resource portfolio that internally embedded in the company, holds the potential for impacting externally to the consumers, in terms of consumer attraction and consumer retention. If so, a critical question on what attributes should be attached to the innovation capability if it will be directed to externally impacting the consumer in the marketplace is important and will be discussed in the following paragraph.

An innovation capability should be developed to attract consumers, as has been discussed in many studies. Adopting the perspective of resource advantage theory of competition (Hunt, 1997, p. 435), a company is continuously striving to provoke disequilibrium in the market place through several innovative moves. To be innovative in coping with market dynamics, a company is developing and enhancing its capability in innovation. This innovation capability is cultivated and internally embedded but has to have power for resonating the produced innovative value into the mind of the consumer that posited externally to the company. Therefore, the ability to innovate products and their related value should be resonated to the consumer's mind. Study on resonating capability and value resonance is rooted in many fields such as in physics, technology, computer science (Braunbrück \& Ravasoo, 2006; Kantabutra \& Avery, 2010; Watanabe, Kanno, \& Tou, 2012), social science (Kopp, 2010) and marketing and consumer science (Ande et al., 2017; Guglielmetti Mugion et al., 2016; Jung Jung et al., 2014; Shang, Wu, \& Sie, 2017; Suarez \& Belk, 2017). As concluded by Braunbrück and Ravasoo (2006) in physics and material science that resonance is sensitive to the wave excitation amplitudes, and the excitation frequency. Adopting the finding of Braunbrück and Ravasoo (2006) to the current study leads us to conceptualize the notion of resonance in building the innovation capability in the following aspects. Firstly, in developing and managing a market orientation-based innovation capability, this capability should be formed with an attribute that has the potential for amplifying excitation to the far and remote external target. Secondly, to capture the attention of the consumers, the innovation capability should have a power for resonating the value of product to be offered. As studied by scholars such as in the work of Shang et al. (2017) we are inclined to insert the idea of innovation capability that boosting particular consumer resonance as the powerful attributes in affecting a user's image of products and, this resonance expands with iterative enforcement by consumers to the broader market place and then lead to the buying intention. Watanabe et al. (2012, p. 1305) signified that "the resonance between signals emitted by innovation tempering consumption and signals emitted by consumers anticipating exciting innovation triggers co-emergence of innovation and consumption" lead to the notion that any innovation capability should be developed and manage to comprise important attributes that potential for resonance the value of offerings produced by an innovation capability. We conceptualize the possibility of value is resonated by the application of technology in the process of innovation of 
product or service is named as techno-resonance innovation capability as described in the following passage.

The advancement of technology exists across companies and industries, then highly adopted in the company's strategic moves primarily in the marketing field through its capability in building the innovation capability. The pivotal role of the technology advancement goes to the possibility of value accentuation in a product/service as supported by the study of Bowman and Ambrosini (2000) that value capture, the realization of exchange value between buyers and sellers depends on how much company accentuate the value. To accentuate the value, may happen in so many marketing activities since planning until controlling activities, products, promotions, pricing, distribution, building customer networks, finding market information, and services to consumers. Rapid and sophisticated technological changes and developments have altered consumer consumption patterns, which are more likely to choose technology-based products. The adoption of technology in innovation creates ways for inserting values that potential for attracting and retaining customers (Foroudi et al., 2016), and triggering the co-emergence of innovation and consumption, eco-value or green attribute of a product (Handayani, Wahyudi, \& Suharnomo, 2017). We arrive then at the specific capability of a techno-resonance innovation capability as a synthesis of the concept of innovation capability - technology adoption and value resonance capability. We conceptualize the techno-resonance innovation capability as an organizational capability in using technology advancement in creating and boosting the value attributes through innovation as a strategic marketing instrument as one of the spirits on the resource advantage theory of competition.

\subsection{Market orientation and techno-resonance innovation capability}

The study of market orientation has been settled in the marketing literature since the seminal work of Kohli and Jaworski (1990) and Jaworski and Kohli (1993), then complemented by their work on the measurement of the concept (Kohli, Jaworski, \& Kumar, 1993) which explained clearly the ontology and the measurement of the market orientation, as well as the related potential antecedence and consequence. Our general understanding on the market orientation is that it is a unity of activity consisting of (1) market intelligence activity to know the needs of consumers as well as the nature of competitor maneuver in the market place, (2) information dissemination of intelligence across departments and company stakeholders, (3) responsiveness of the company to their external stakeholders as appeared in marketing scholars studies and perceived as a strategic input of organization in striving for better marketing performance.

As mentioned before, market orientation is a potential driver for innovation capability in a sense that the possession of a strong market orientation may result in superior firm performance, but still a necessity to identify the action for initiating the enhancement of a kind of innovation capability that hold potentials for enhancing marketing performance. The market orientation might be a strategic instrument for accentuating the resonance of innovation to the consumer for a high-demand consumption through the techno-resonance innovation capability - a capability of innovation that equipped by technology support in creating and boosting or resonating the technological value attribute embedded in the product or service. Therefore, the following hypothesis is proposed.

$\mathrm{H}_{1}$ : Market orientation has a positive influence on techno-resonance innovation capability.

\subsection{Techno-resonance innovation capability and product innovativeness}

The advantages of technological resources become one of the critical factors that determine the success of product innovation. Products with superior value as the degree of innovation will result in better product innovativeness as a consequence of a firm's context-specific capability as compared to competitors' products. Product innovation based on technological exploration capability and empowered by attributes that potential for impacting to enhancing value for a consumer such as healthy food, aesthetic value, as well as green attributes of a product will giving impact on the appearance of certain innovativeness. The innovative appearance of a product is achieved from the technology-based innovation. Technology-based innovation can be defined as superior creativity to develop ideas, learn a process and find solutions to problems in the face of alternative problem-solving options that deliver superior value to consumers, based on the technological advantages of resource diversification.

Companies that adopt the technological advantages in the process of innovating products and or services tend to be more efficient and effective in serving the marketplace. A product innovation that is developed with specific technological attributes, in terms of the sophistication of the product features such as the technology-based precision of product appearance, the technology-based healthiness of the product, the stability color, taste of the product, the endurance of the packaging as a result of the application of technology, could become a boosting power for resonating the product value to its target markets. Exploiting technological resources in terms of technological attributes embedded in a product or service is the key to success and improving the company's marketing performance. High ability of product innovation will have an impact on the increases in revenues and profits (Ilg, 2019) due to its ability to improve efficiency and effectiveness of production. Literatures demonstrates the technology-based product innovation is a prerequisite for enhancing product innovativeness in terms of acculturative product uniqueness (Sugiyarti, Ferdinand, \& Nurchayati, 2018), or the attractiveness of the visual arts embedded in the product. If this capability could be formed with specific attributes that hold potential in resonating the values of the product, 
accentuating the technological attributes of the product, hence it is rational to propose the following hypothesis.

H2: Techno-resonance innovation capability has a positive influence on product innovativeness

Research on value resonance provides ways for discussing the consequence of a company that accentuates value for every product or service offered into the marketplace. As mentioned in the study of Sok and O'Cass (2015), the possession of a product innovation capability holds the potential to enhance firm performance compared to major competitors in terms of marketing profitability as well as the return on sales. Lending the study Sharma and Jasrotia (2016), a product with value, both functional and emotional, as supported by the technological content for excellent functioning, will get a high brand value resonance leading to higher marketing performance. As such, the following hypothesis is proposed.

$\mathrm{H}_{3}$ : Techno-resonance innovation capability has a positive influence on marketing performance.

Considering our research gap on the inconsistent findings of the influence of market orientation to marketing performance, we insert the techno-resonance innovation capability as a stepping stone for enhancing marketing performance. Therefore, techno-resonance innovation capability is designed as a mediating variable. This research design is based on the following reasons. Market orientation is defined as activities for collecting consumer information and competitor information and disseminating that information across divisions in an organization. In a micro-management level, market information is providing and sharing within a company or organization as an input or driver for enhancing marketing performance (Ngek Neneh, 2016), on the study of de Guimarães, Severo, and de Vasconcelos (2018) is a driver or input for enhancing performance through a process of value delivering, innovativeness. As marketing orientation is recognized as an informative strategic input for enhancing performance through several capabilities and business practices, such as in creating value, accentuate value (Chowdhury, Desai, \& Bolton, 2014; Groening, Sarkis, \& Zhu, 2018; Islam, 2018; Kristina \& Tore, 2015; Le et al., 2018; Sahibzada Jawad et al., 2019). This notion leads to conceptualize the techno-resonance innovation capability as a strategic asset that holds the potentials for enhancing performance. Therefore, a mediation hypothesis is proposed.

$\mathrm{H}_{4}$ : Techno-resonance innovation capability mediates the influence on market orientation to marketing performance.

\subsection{Product innovation and marketing performance}

Consumers are always looking for products that provide more value when used. An influential culture of market orientation that aims to provide high value to consumers could be realized by providing an innovative product that offers a specific competitive advantage (Langerak, Hultink, \& Robben, 2004). The innovative product is the product's competitive edge and specific characteristics that are the result of the innovation process that employs technological advantages (Akgün et al., 2007; Calantone, Chan, \& Cui, 2006; Langerak et al., 2004; McNally, Cavusgil, \& Calantone, 2010).

The ability to produce innovative products is strongly supported by technological developments, as technologybased companies can improve efficiency and effectiveness in producing products (Garcia \& Calantone, 2002; Li \& Atuahene-Gima, 2001). Increases in the competition are not only contributed by competitors' products but also by the existence of counterfeit products that offer the same looks, like the original products. Both products play roles in product performance. The development of counterfeit products produced by competitors will encourage companies to always protect and improve product performance through innovation processes that produce innovative products that will become increasingly difficult to be imitated by a competing product (Calantone et al., 2006).

Product innovation shows the development and progress of product functionality, which can provide a clear picture to the consumer that the product innovativeness produced has superior value for the consumer. Innovative products can be described as new products, new markets, and superior products that adapt to consumers' needs (Lee \& Colarelli O'Connor, 2003; Zhou, Yim, \& Tse, 2005). Product innovation aims to improve product performance, so the success of product innovation is highly dependent on the company's ability to produce superior value to customers. Companies with a deep market-oriented culture understand the needs and desires of customers and use it as the basis for innovative product innovation (Low, Chapman, \& Sloan, 2007). Thus, the performance of product innovativeness does not only depend on product orientation but also depends on how well the company understands customer needs.

The right product innovation strategy would produce an excellent performance on product innovativeness; thus it can support marketing performance (Akgün et al., 2007; Avlonitis \& Salavou, 2007; Calantone et al., 2006; McNally et al., 2010; Zhang \& Duan, 2010). Marketing performance is a measure of the success of the company's marketing activities. The importance of measuring marketing performance is because different organizational cultures and leadership styles affect the company's view of the success of on-going marketing activities. Based on the research undertaken by Baker and Sinkula (2009), marketing performance is measured through profitability in terms of sales value, changes in profits, and changes in the percentage of earnings. Additionally, Avlonitis and Gounaris (1997) measure marketing performance through profits, annual turnover, ROI, and market share. A study conducted by Gao, Zhou, and Yim (2007) measures the company's performance using the size of the value of profitability, sales growth, and product performance. The current study concludes that the primary purpose of the company's performance is to generate value that can contribute to profit level, profit percentage, sales growth, and customer growth.

Several previous studies explained that innovation has a negative impact on marketing performance in terms of 
return on investment (Low et al., 2007). The negative results are caused by the payback period for the resources used in the innovation process. Product innovation policies aimed at enhancing product innovativeness can improve marketing performance (Akgün et al., 2007; Avlonitis \& Salavou, 2007; Calantone et al., 2006; Fang, 2008; Fu \& Elliott, 2013; McNally et al., 2010). Based on the results of studies on innovativeness products on the performance of corporate marketing, this study constructs hypothesis $\mathrm{H}_{5}$ as follow:

$\mathrm{H}_{5}$ : Product innovativeness has a positive influence on marketing performance.

\section{Research method}

\subsection{Sample and data collection}

Data are collected from small and medium enterprises (SMEs) owners or managers who are eligible to represent the company in West Kalimantan (West Borneo) Province di Indonesia. A total number of 121 SMEs were invited to and voluntarily participated in this research, represented by the owner-managers based on a convenience sample frame. These SMEs are working in producing and marketing a series of green and regio-centric and or regio-iconic food and beverage products which produced, packaged, and branded using appropriate technology for securing greeny, quality, and healthiness. The category of products is presented in Table 1. The researchers arranged an informal meeting with the owner-manager and conducted a structured interview aided by a set of questionnaires, asking questions, then fill up the questionnaire item related to the research model. In total, we have 121 respondents with complete data for finalizing this research.

\subsection{Measurement of the instrument's validity and reliability}

The measurement of the variables used in this study is adapted from previous relevant studies. We adapted the study of Lee et al. (2015) and Long et al. (2017) which using the indicator of Consumer Information, Competitor Information, Market Related Information Coordination for measuring the market orientation. The Product Innovativeness measurement is adapted from the previous studies of (Ramkumar, 2016) and (Jaeger et al., 2017) as product uniqueness, product inimitability, and product variability. The techno-resonance innovation capability is a newly developed scale, and we argue that if a product is developed using technology for guaranteeing the stability of quality and attractiveness of the product, particularly food-based products by SMEs, the technology-based product itself could hold a resonating power for consumers. The main reason is that a capability of innovation that equipped by technology support in creating and boosting or resonating the technological value attribute embedded in the product or service will emboss the attractiveness of the created value. We adopted several scales such as of Zhou et al. (2005), "We use technologies in our product development," and the scale of O'Cass and Sok (2013) such as "Exploiting the most up-to-date technology available in developing new product" for developing our scale of "we have skill for using technology in designing our product" in short-form "technology-based product innovation capability" and "we have skill for configuring the elements of design" in short-form "technology-based configuring skills." We adopt the study of Sullaida, Nurmala, and Ahyar (2018) of the ability to develop a capability for crafting the regional-origin product (Sullaida et al., 2018) in formulating our scale "we have skill for using technology in crafting the motif of products and packaging in short form "Technology-based motif crafting capability." Lending the Study of (Adam et al., 2014) which concluded that producer-farmers are able to merchandise products to accentuate the value of a product through differentiation strategies lead us to formulate our scale as "we are able to accentuate the value of our product features using technology," in short-form "Technology-based features accentuation skill. Marketing performance is measured using the

Table 1. Research sample

\begin{tabular}{|l|c|c|c|c|c|c|}
\hline \multirow{2}{*}{ Category of product } & $\begin{array}{c}\text { Number of SMEs Entity } \\
\text { Samples }\end{array}$ & \multicolumn{2}{c|}{ On-line Selling } & \multicolumn{2}{c|}{ Off-line selling } \\
\cline { 2 - 7 } & Frequency & Percentage & Frequency & Percentage & Frequency & Percentage \\
\hline Bread and Ordinary Bakery Wares & 45 & $37 \%$ & 35 & $45 \%$ & 10 & $23 \%$ \\
\hline $\begin{array}{l}\text { Dairy-based desserts (e.g., ice cream, ice milk, } \\
\text { pudding,fruit or flavoured yoghurt) }\end{array}$ & 16 & $13 \%$ & 10 & $13 \%$ & 6 & $14 \%$ \\
\hline Fermented fruit products & 23 & $19 \%$ & 12 & $16 \%$ & 11 & $25 \%$ \\
\hline $\begin{array}{l}\text { Confectionery including hard and soft candy, } \\
\text { nougats, etc. }\end{array}$ & 3 & $2 \%$ & 2 & $3 \%$ & 1 & $2 \%$ \\
\hline $\begin{array}{l}\text { Regio-centric-smoked, dried, fermented, and/or } \\
\text { salted fish and fish products }\end{array}$ & 24 & $20 \%$ & 11 & $14 \%$ & 13 & $30 \%$ \\
\hline $\begin{array}{l}\text { Regio-centric canned or bottled (pasteurized) } \\
\text { fruit juice and vegetable juice) }\end{array}$ & 10 & $8 \%$ & 7 & $9 \%$ & 3 & $7 \%$ \\
\hline Total & 121 & $100 \%$ & 77 & $100 \%$ & 44 & $100 \%$ \\
\hline
\end{tabular}


scale of Setiawan and Hanfan (2017) and Sugiyarti et al. (2018) comprising sales growth, sales profitability, and customer growth. All scales item is presented in Table 2, which measured by a score range of 1 to 5 .

\section{Research method}

\subsection{Measurement of validity and reliability}

We used the structural equation model- SEM technique with the AMOS software 23, for testing the hypotheses, based on several considerations. Firstly, SEM is capable for simultaneously solving several equations compared to ordinary regression analysis as in the standard package $\mathrm{pf}$ SPSS with interchanging dependent and independent variables (Kroehne, Funke, \& Steyer, 2003) as in our model. Secondly, SEM has the capability of testing the mediational effect in a simultaneous process (Tabachnick \& Fidell, 2012). Data from the 121 respondents were analyzed in a full model for observing the validity of our research instrument validity and reliability of measurement, as is presented in Table 2, followed by the testing of our proposed hypotheses, as is presented in Table 3.

As presented in Table 2, all variables have a positive factor loading with a critical ratio $\geq 2.0$, indicating an accepted significant loading value for mirroring its latent variable. All variables were measured and mirrored by adequate regression weight as positive factor loading with significant critical ratio $\geq 2.0$ (Arbuckle, 2016) indicated the well-acceptance of the indicators of all related variables. The convergent validity indices for the variables demonstrate the adequacy measures by observing the standardized factor loading. The result is all variables have the acceptance level of the cut-off value $0.50-0.70$ (Hair et al., 2010), indicating a well-accepted convergent validity, our measurement of Average of Variance Extracted - AVE resulted in Market orientation (0.555), Techno-resonance innovation capability (0.525), Product innovativeness (0.531), Marketing Performance (0.532). All AVE criteria are above the cut-off value of 0.50 , indicating the acceptance of the validity of the instrument used for this research. All of the four latent variables have

Table 2. Measurement of validity and reliability

\begin{tabular}{|c|c|c|c|c|}
\hline VARIABLE \& INDICATOR & SCALE ITEM & REFERENCE & $\begin{array}{l}\text { STD. } \\
\text { LOADING } \\
\text { (Lambda } \\
\text { Value ) }\end{array}$ & $\begin{array}{l}\text { Critical } \\
\text { Ratio } \\
\geq 1.96\end{array}$ \\
\hline \multicolumn{2}{|c|}{$\begin{aligned} \text { Market orientation - Convergent Validity - AVE } & =0.555 \\
\text { Construct Reliability - CRI } & =0.785\end{aligned}$} & \multirow{4}{*}{$\begin{array}{l}\text { Lee, Kim, Seo, } \\
\text { \& Hight, 2015; } \\
\text { Long, Ali, } \\
\text { John, \& Alma, } \\
2017\end{array}$} & & \\
\hline - Consumer Information & $\begin{array}{l}\text { - Our company quickly responds to changes in } \\
\text { customers' product preferences. }\end{array}$ & & 0.700 & 6.019 \\
\hline - Competitor Information & $\begin{array}{l}\text { - All members in our company share important } \\
\text { information about our competitors. }\end{array}$ & & 0.900 & 5.495 \\
\hline $\begin{array}{l}\text { - Market Related Information } \\
\text { Coordination }\end{array}$ & $\begin{array}{l}\text { - Our teams work discuss together changes in ge } \\
\text { market plalce to improve our products by focusing } \\
\text { on our customers' demand }\end{array}$ & & 0.605 & 5.495 \\
\hline \multicolumn{2}{|c|}{ Techno-resonance innovation capability $-\mathrm{AVE}=0.525 ; \mathrm{CRI}=0.815$} & \multirow{5}{*}{$\begin{array}{l}\text { Adapted from } \\
\text { Adam et al., } \\
\text { 2014; O'Cass } \\
\text { and Sok, 2013; } \\
\text { Sullaida et al., } \\
\text { 2018; Zhou } \\
\text { et al., } 2005\end{array}$} & & \\
\hline $\begin{array}{l}\text { - Technology-based designing } \\
\text { capability }\end{array}$ & $\begin{array}{l}\text { - We have skill for using technology in designing } \\
\text { our product }\end{array}$ & & 0.762 & 6.641 \\
\hline $\begin{array}{l}\text { - Technology-based configuring } \\
\text { skill }\end{array}$ & $\begin{array}{l}\text { - We have skill for configuring the elements of } \\
\text { design }\end{array}$ & & 0.742 & 6.169 \\
\hline $\begin{array}{l}\text { - Technology-based features } \\
\text { accentuation skill }\end{array}$ & $\begin{array}{l}\text { - We are able to accentuate the value of our product } \\
\text { features using technology }\end{array}$ & & 0,630 & 6,406 \\
\hline $\begin{array}{l}\text { - Technology-based motif } \\
\text { crafting skills }\end{array}$ & $\begin{array}{l}\text { - We have skill for using technology in crafting the } \\
\text { motif of products and packaging }\end{array}$ & & 0.757 & 6.406 \\
\hline \multicolumn{2}{|c|}{ Product innovativeness $-\mathrm{AVE}=0.531 ; \mathrm{CRI}=0.771$} & \multirow{4}{*}{$\begin{array}{l}\text { Jaeger } \\
\text { et al., 2017; } \\
\text { Ramkumar, } \\
2016\end{array}$} & & \\
\hline - Product Uniqueness & $\begin{array}{l}\text { - Our products are often perceived as novel and } \\
\text { unique by customers. }\end{array}$ & & 0.642 & 5.823 \\
\hline - Product Inimitability & $\begin{array}{l}\text { - Our product has inimitable styling and features } \\
\text { that are rare to find }\end{array}$ & & 0.742 & 5.823 \\
\hline - Product Variability & $\begin{array}{l}\text { - Our new products are major changes from our } \\
\text { previous products with a wide range of variability }\end{array}$ & & 0.793 & 6.045 \\
\hline \multicolumn{2}{|c|}{ Marketing performance $-\mathrm{AVE}=0.532 ; \mathrm{CRI}=0.768$} & \multirow{4}{*}{$\begin{array}{l}\text { Setiawan and } \\
\text { Hanfan, 2017; } \\
\text { Sugiyarti, } \\
\text { Ferdinand, } \\
\text { and Nurcha- } \\
\text { yati, } 2018\end{array}$} & & \\
\hline - Sales Growth & - Our sales in growing & & 0.646 & 6.375 \\
\hline - Sales profitability & - We always keep ketting profit from our sales & & 0.902 & 7.575 \\
\hline - Customer Growth & - We always have a positive growth of customer & & 0.605 & 7.575 \\
\hline
\end{tabular}


good reliability as measured by construct reliability index $-\mathrm{CRI} \geq 0.70$ (Hair et al., 2010), such as 0.785 for Marketing Orientation, 0.815 for Techno-Resonance Innovation Capability, 0.771 for Product Innovativeness, and 0.768 for Marketing Performance. As the validity and reliability of our data instrument have met the required cut-off value, we proceed to the process of hypothesis testing.

\subsection{Hypothesis testing}

In order to test our hypotheses, the Structural Equation model AMOS 23 Software was used to test the model and all related hypotheses. The result is as presented in Figure 1.

Based on the results of a two-step SPSS AMOS 23 hypotheses testing procedure, we get the result as follows.

Table 3. Hypothesis testing criteria

\begin{tabular}{|c|c|c|c|c|c|c|}
\hline & Hipotesis Variable & $\begin{array}{c}\text { Standardized } \\
\text { Estimate }\end{array}$ & Estimate & CriticalRatio & $\mathrm{P}$ & Conclusion \\
\hline $\mathrm{H} 1$ & $\begin{array}{l}\text { Market orientation has a positive influence on } \\
\text { techno-resonance innovation capability. }\end{array}$ & 0.443 & 0.464 & 3.410 & $* * *$ & Supported \\
\hline $\mathrm{H} 2$ & $\begin{array}{l}\text { Techno-resonance innovation capability has a } \\
\text { positive influence on product innovativeness }\end{array}$ & 0.488 & 0.463 & 3.608 & $* * *$ & Supported \\
\hline $\mathrm{H} 3$ & $\begin{array}{l}\text { Techno-resonance innovation capability has a } \\
\text { positive influence on marketing performance }\end{array}$ & 0.549 & 0.705 & 3.975 & $* * *$ & Supported \\
\hline $\mathrm{H} 4$ & $\begin{array}{l}\text { Techno-resonance innovation capability } \\
\text { mediates the influence of market orientation } \\
\text { to marketing performance }\end{array}$ & $\begin{array}{l}\text { Full-mediation } \\
\text { At the Baron \& } \\
\text { was inserted, } t \\
\text { performance }\end{array}$ & $\begin{array}{l}\text { enfect is cor } \\
\text { enny's pro } \\
\text { regressio } \\
\text { came insig }\end{array}$ & $\begin{array}{l}\text { dure number fo } \\
\text { weight of mark } \\
\text { ficant. }\end{array}$ & $\begin{array}{l}\text { ur, when th } \\
\text { et orientati }\end{array}$ & $\begin{array}{l}\text { lediation } \\
\text { o marketing }\end{array}$ \\
\hline & $\mathrm{P} 1: \mathrm{MO} \rightarrow \mathrm{MP}$ & 0.357 & 0.463 & 2.942 & 0.003 & Supported \\
\hline & P2: MO $\rightarrow$ TRIP & 0.414 & 0.419 & 3.176 & 0.001 & Supported \\
\hline & P3: TRIP $\rightarrow$ MP & 0.661 & 0.878 & 4.942 & $* * *$ & Supported \\
\hline & $\mathrm{P} 4: \mathrm{MO} \rightarrow \mathrm{MP}$ & 0.101 & 0.137 & 0.039 & 0.348 & Not supported \\
\hline H5 & $\begin{array}{l}\text { Product innovativeness has a positive } \\
\text { influence on marketing performance }\end{array}$ & 0.245 & 0.331 & 2.050 & 0.040 & Supported \\
\hline \multicolumn{4}{|c|}{ Goodness of fit Test } & Cut-off Value & Result & Conclusion \\
\hline \multicolumn{4}{|c|}{ Chi-square for $\mathrm{DF}=61$ at a significance level $5 \%$} & 80.232 & 78.092 & Fit \\
\hline \multicolumn{4}{|c|}{ Significance } & $\geq 0.05$ & 0.069 & Fit \\
\hline \multicolumn{4}{|c|}{ The goodness of Fit Index } & $\geq 0.90$ & 0.919 & Fit \\
\hline \multicolumn{4}{|c|}{ The Adjusted Goodness of Fit Index } & $\geq 0.90$ & 0.878 & Marginal Fit \\
\hline \multicolumn{4}{|c|}{ Comparative Fit Index } & $\geq 0.90$ & 0.969 & Fit \\
\hline \multicolumn{4}{|c|}{ Tucker Lewis Index } & $\geq 0.90$ & 0.960 & Fit \\
\hline \multicolumn{4}{|c|}{ RMSEA-Root mean square error of approximation } & $0.03-0.08$ & 0.048 & Fit \\
\hline
\end{tabular}

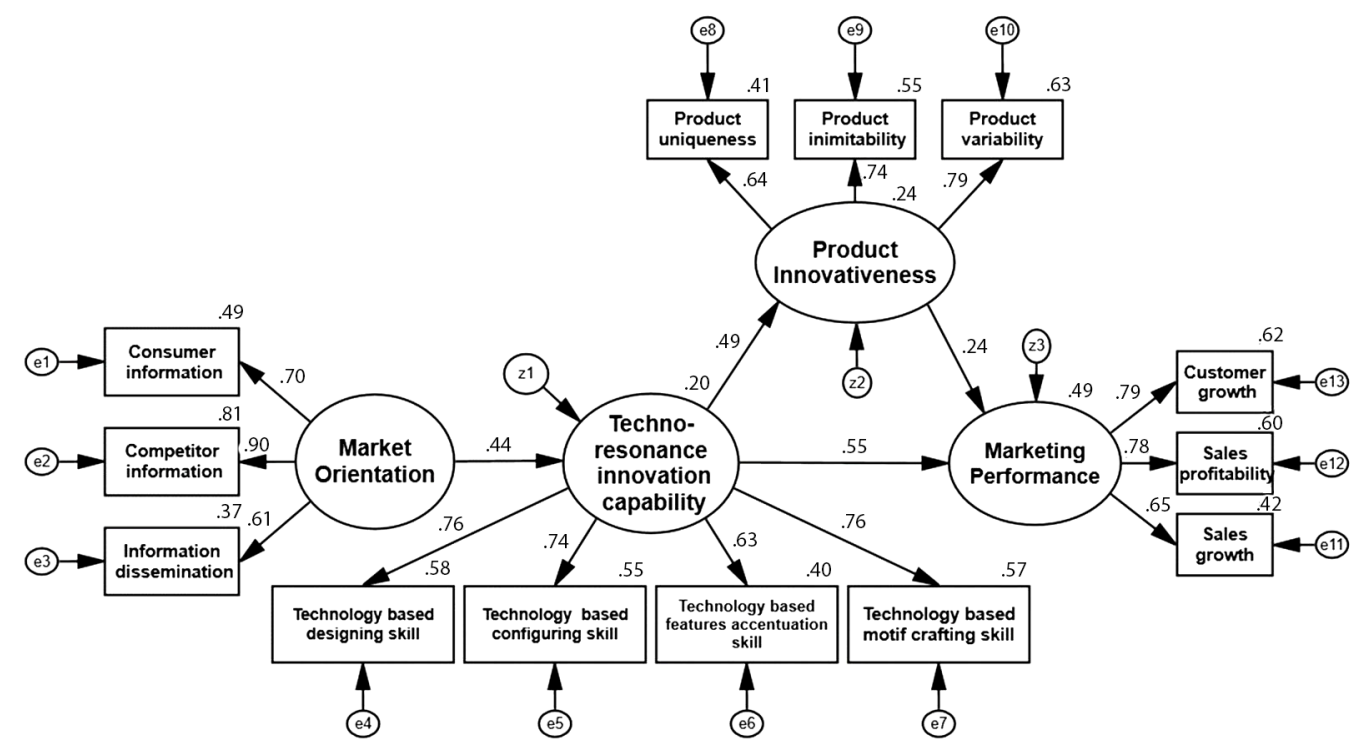

Figure 1. Full structural model - Techno-resonance innovation capability 
The first step is testing the goodness of fit of the model resulting in a good acceptance model as presented in Table 3 with a chi-square level of significance $=0.069$; GFI (0.918), CFI (0.969), TLI (0.960), RMSEA (0.048). All criteria are above the cut-off value level, indicating the acceptance of our model.

The second step is then testing the regressional hypothesis as well as the mediation hypothesis, as discussed in the previous section of this article. As presented in Table 3, the critical ratio for all regressional hypotheses is above the cut-off value of 2.0 (Arbuckle, 2016); therefore, those hypotheses are well accepted.

As the techno-resonance innovation capability was selected as a mediation between market orientation and marketing performance to solve the research gap on the inconsistent finding of influence of market orientation on marketing performance, we need to test the mediating effect hypothesis. We were adopting the Baron and Kenny (1986) procedure for testing the mediation effect, that 1 . There should be a significant regression coefficient of independent to dependent variable; 2 . There should be a significant regression coefficient of the independent variable to the mediation variable; 3 . There should be a regression coefficient of the mediation variable to the dependent variable; 4 . The significant regression coefficient of independent to a dependent variable should be significantly reduced or become insignificant when the mediation variable is inserted in the model. To do so, we rerun the model with four steps, as presented at the bottom of Table 3. When the techno-resonance innovation capability is inserted in the model, the effect of market orientation on marketing performance is changing lower ( 0.357 decreases to 0.101) and insignificant, indicating the existence of a full mediating effect of the techno-resonance innovation capability to fill up the gap between market orientation and marketing performance.

\section{Research conclusions and direction for future research}

\section{Research conclusion}

This study aims to build a conceptual model on how to manage market orientation that holds the potential for enhancing marketing performance through a synthesis of the techno-resonance innovation capability. The acceptance of our proposed hypothesis provides several conclusions in managing market orientation for enhancing marketing performance. Firstly, strengthening the R-A Theory-based on the study of Ejdys (2015), de Guimarães et al. (2018), and (Le et al., 2018) that recognizing market orientation as a strategic asset or strategic driver for enhancing marketing performance. This strategic driver is proved as an effective tool for enhancing the technoresonance innovation capability which strengthening the study of innovation capability (Adam et al., 2014; Chung, 2019; De Guimarães, Severo, Campos, El-Aouar, \& Azevedo, 2019; Huhtala et al., 2014; Sullaida et al., 2018) as a strategic leverage for enhancing marketing performance. The logic behind this path is that market orientation is an initial step for enhancing capabilities in innovating as a means for provoking disequilibrium in the market place through the innovativeness offerings in the market place as discussed in the core concept of RA-Theory (Hunt, 2013). As the techno-resonance innovation capability is developed for providing value-oriented products and services, it holds the potentials for enhancing the marketing performance. Secondly, A market-oriented company might be creating ways to enhance its techno-resonance innovation capability as a strategic asset for enhancing product innovativeness. This process is in line with the R-A theory (Hunt, 1997) could be recognized as a strategic pathway for provoking disequilibrium of consumer choices by providing and offering a new alternative for consumers. However, the rejection of the direct influence of product innovativeness to marketing performance provides us a theoretical insight that innovativeness itself is essential but not sufficient for enhancing performance, as proved in the study of Prifti and Alimehmeti (2017). It is a necessity for finding a process on how the uniqueness of a product is resonated to attract consumers to buy a product.

\section{Managerial implication}

The acceptance and rejection of the hypothesis reveal several managerial implications, particularly for the SMEs in struggling for better performance in the competitive market. First, developing a specific capability in innovating products or services could be more effective if it is based on an appropriate technology that potential for autoresonating the effect of technology applied in producing product ad service. To do so, this may appear such as for guaranteeing the stability of product quality, especially for food-product, green product, herbal product, ensure the precision of product specification as taste, the weight of the product, support the durability of the product as well as the endurance of the packaging. Second, the rejection of our hypothesis on the influence of product innovativeness to marketing performance brings an implication for SMEs manager to care about steps after having the innovative products in their product portfolio, such as conducting media or events for resonating the innovative value of the product for enhancing marketing performance.

\section{Limitation and future research}

This study has several limitations, firstly, the result of our model goodness-of-fit test shows that not all the criteria meet the cut-off value standard, such as the marginal of AGFI value of 0.878 . Therefore, the model needs further improvement and refinement by adding some new variables, and or replication of this study to a bigger sample size will be a new research direction in the future. Secondly, a study on techno-resonance innovation capability is still at the very beginning; the replication of the study across industries is an alternative for testing the concept as 
well as the model. Thirdly, the rejection of our hypothesis on the influence of product innovativeness on marketing performance provides a research venue for developing a mediation process between product innovation and marketing performance.

\section{Acknowledgements}

We express our special thanks to all of the SME managers who have voluntarily participated in our research, and extend our appreciation to Maria Immacula Prettyfernandy, a former staff of the Thompson Reuter Manila Office for her support in translating the first draft of this manuscript.

\section{Funding}

This research is personally funded by the authors.

\section{Author contributions}

All author have equal contribution to the research process

Lauw Sun Hiong is responsible for the preparation of the first draft of the manuscript and all processes of data collection and analysis.

Augusty Tae Ferdinand is responsible for revising the first manuscript and responding to the reviewer's comment after several online discussions between the authors and finalizing the manuscript, managing the online submission of the article.

Erna Listiana is responsible for the discussion of the findings - conclusions and implication.

\section{Disclosure statement}

We, the authors of this research article, have no competing or conflicting interest in the finalization and publication of this research article.

\section{References}

Adam, D., Tropp, D., Barham, J., Muldoon, M. F., Kiraly, S., \& Cantrell., P. (2014). Food value chainsl creating shared value to enhance marketing success. U.S. Dept. of Agriculture, Agricultural Marketing Service.

Akgün, A. E., Keskin, H., Byrne, J. C., \& Aren, S. (2007). Emotional and learning capability and their impact on product innovativeness and firm performance. Technovation, 27(9), 501-513. https://doi.org/10.1016/j.technovation.2007.03.001

Ande, R. A., Gunasekaran, A., Murugesan, P., \& Natarajan, T. (2017). Brand resonance score for CBBE model: an application in financial services. Benchmarking: An International Journal, 24(6), 1490-1507.

https://doi.org/10.1108/BIJ-07-2015-0073

Arbuckle, J. L. (2016). IBM ${ }^{\circledast}$ SPSS $^{\oplus}$ Amos $^{\text {TM }}$ User's Guide.

Asia Pacific Foundation of Canada, A. (2018). 2018 survey of entrepreneurs and MSMEs in Indonesia - building the capacity of MSMEs through human capital.

Avlonitis, G. J., \& Gounaris, S. P. (1997). Marketing orientation and company performance: industrial vs. consumer goods companies. Industrial Marketing Management, 26(5), 385402. https://doi.org/10.1016/S0019-8501(96)00121-6
Avlonitis, G. J., \& Salavou, H. E. (2007). Entrepreneurial orientation of SMEs, product innovativeness, and performance. Journal of Business Research, 60(5), 566-575. https://doi.org/10.1016/j.jbusres.2007.01.001

Baker, W. E., \& Sinkula, J. M. (2009). The complementary effects of market orientation and entrepreneurial orientation on profitability in small businesses. Journal of Small Business Management, 47(4), 443-464. https://doi.org/10.1111/j.1540-627X.2009.00278.x

Baron, R., \& Kenny, D. (1986). The moderator-mediator variable distinction in social psychological research: conceptual, strategic, and statistical considerations. Journal of Personality and Social Psychology, 51(6), 1173-1182. https://doi.org/10.1037/0022-3514.51.6.1173

Bowman, C., \& Ambrosini, V. (2000). Value creation versus value capture: Towards a coherent definition of value in strategy. British Journal of Management, 11(1), 1-15. https://doi.org/10.1111/1467-8551.00147

Braunbrück, A., \& Ravasoo, A. (2006). Wave interaction resonance in weakly inhomogeneous nonlinear elastic material. Wave Motion, 43(3), 277-285. https://doi.org/10.1016/j.wavemoti.2005.11.001

Cacciolatti, L., \& Lee, S. H. (2016). Revisiting the relationship between marketing capabilities and firm performance: The moderating role of market orientation, marketing strategy and organisational power. Journal of Business Research, 69(12), 5597-5610. https://doi.org/10.1016/j.jbusres.2016.03.067

Calantone, R. J., Chan, K., \& Cui, A. S. (2006). Decomposing product innovativeness and its effects on new product success. Journal of Product Innovation Management, 23(5), 408421. https://doi.org/10.1111/j.1540-5885.2006.00213.x

Cheng, C. C., \& Huizingh, E. K. (2014). When is open innovation beneficial? The role of strategic orientation. Journal of Product Innovation Management, 31(6), 1235-1253. https://doi.org/10.1111/jpim.12148

Chowdhury, T. G., Desai, K. K., \& Bolton, L. (2014). Accentuate the positive: how identity affects customer satisfaction. Journal of Consumer Marketing, 31(5), 10.

https://doi.org/10.1108/JCM-03-2014-0915

Chung, H. F. L. (2019). How guanxi networking matters in the relation between market orientation and innovation in Asian emerging economies - the case of Markor. Journal of Business \& Industrial Marketing, 34(4), 836-849. https://doi.org/10.1108/JBIM-05-2017-0115

De Guimarães, J. C. F., Severo, E. A., Campos, D. F., ElAouar, W. A., \& Azevedo, F. L. B. d. (2019). Strategic drivers for product and process innovation. Benchmarking: An International Journal, 27(3).

https://doi.org/10.1108/BIJ-12-2018-0403

de Guimarães, J. C. F., Severo, E. A., \& de Vasconcelos, C. R. M. (2018). The influence of entrepreneurial, market, knowledge management orientations on cleaner production and the sustainable competitive advantage. Journal of Cleaner Production, 174, 1653-1663. https://doi.org/10.1016/j.jclepro.2017.11.074

Ejdys, J. (2015). Market orientation vs. inovativeness of SMEs of Podlaskie province. Verslas: teorija ir praktika, 16(4), 353361. https://doi.org/10.3846/btp.2015.563

Etkin, J. (2016). Choosing variety for joint consumption. Journal of Marketing Research, 53(6), 1019-1033. https://doi.org/10.1509/jmr.14.0209

Fang, E. (2008). Customer participation and the trade-off between new product innovativeness and speed to market. Journal of Marketing, 72(4), 90-104. https://doi.org/10.1509/jmkg.72.4.090 
Fernandes, C. I. M. A. S., Ferreira, J. J. M., Lobo, C. A., \& Raposo, M. (2020). The impact of market orientation on the internationalisation of SMEs. Review of International Business and Strategy (ahead-of-print).

https://doi.org/10.1108/RIBS-09-2019-0120

Foroudi, P., Jin, Z., Gupta, S., Melewar, T. C., \& Foroudi, M. M. (2016). Influence of innovation capability and customer experience on reputation and loyalty. Journal of Business Research, 69(11), 4882-4889.

https://doi.org/10.1016/j.jbusres.2016.04.047

Fu, F. Q., \& Elliott, M. T. (2013). The moderating effect of perceived product innovativeness and product knowledge on new product adoption: an integrated model. Journal of Marketing Theory and Practice, 21(3), 257-272. https://doi.org/10.2753/MTP1069-6679210302

Gao, G. Y., Zhou, K. Z., \& Yim, C. K. B. (2007). On what should firms focus in transitional economies? A study of the contingent value of strategic orientations in China. International Journal of Research in Marketing, 24(1), 3-15. https://doi.org/10.1016/j.ijresmar.2006.09.004

Garcia, R., \& Calantone, R. (2002). A critical look at technological innovation typology and innovativeness terminology: a literature review. Journal of Product Innovation Management, 19(2), 110-132. https://doi.org/10.1111/1540-5885.1920110

Groening, C., Sarkis, J., \& Zhu, Q. (2018). Green marketing consumer-level theory review: A compendium of applied theories and further research directions. Journal of Cleaner Production, 172, 1848-1866.

https://doi.org/10.1016/j.jclepro.2017.12.002

Guglielmetti Mugion, R., Aal, K., Renzi, M. F., Di Pietro, L., \& Edvardsson, B. (2016). Innovation in service ecosystems: An empirical study of the integration of values, brands, service systems and experience rooms. Journal of Service Management, 27(4), 619-651.

https://doi.org/10.1108/JOSM-02-2015-0044

Hair, J. F., Black, W. C., Babin, B. J., \& Anderson, R. E. (2010). Multivariate data analysis (7th ed.). Pearson Prentice Hall.

Handayani, R., Wahyudi, S., \& Suharnomo, S. (2017). The effects of corporate social responsibility on manufacturing industry performance: the mediating role of social collaboration and green innovation. Business: Theory and Practice, 18(1), 152159. https://doi.org/10.3846/btp.2017.016

Huhtala, J.-P., Sihvonen, A., Frösén, J., Jaakkola, M., \& Tikkanen, H. (2014). Market orientation, innovation capability and business performance: Insights from the global financial crisis. Baltic Journal of Management, 9(2), 134-152.

https://doi.org/10.1108/BJM-03-2013-0044

Hunt, S. D. (1997). Competing through relationships: Grounding relationship marketing in resource-advantage theory. Journal of Marketing Management, 13(5), 431-445.

https://doi.org/10.1080/0267257X.1997.9964484

Hunt, S. D. (2001). Commentary - A General Theory of Competition: issues, answers and an invitation. European Journal of Marketing, 35(5/6), 524-548.

https://doi.org/10.1108/03090560110388097

Hunt, S. D. (2013). A general theory of business marketing: R-A theory, Alderson, the ISBM framework, and the IMP theoretical structure. Industrial Marketing Management, 42(3), 283-293. https://doi.org/10.1016/j.indmarman.2013.02.002

Hunt, S. D., \& Morgan, R. M. (1997). Resource-advantage theory: A snake swallowing its tail or a general theory of competition? Journal of Marketing, 61(4), 74-82. https://doi.org/10.1177/002224299706100406
Ilg, P. (2019). How to foster green product innovation in an inert sector. Journal of Innovation \& Knowledge, 4(2), 129-138. https://doi.org/10.1016/j.jik.2017.12.009

Islam, S. (2018). Understanding health consumer value: service marketing perspective. South Asian Journal of Business Studies, 7(1), 2-21. https://doi.org/10.1108/SAJBS-04-2017-0051

Jaeger, S. R., Cardello, A. V., Jin, D., Hunter, D. C., Roigard, C. M., \& Hedderley, D. I. (2017). Product uniqueness: Further exploration and application of a consumer-based methodology. Food Quality and Preference, 60, 59-71.

https://doi.org/10.1016/j.foodqual.2017.03.013

Jaworski, B. J., \& Kohli, A. K. (1993). Market orientation antecedents and consequences. Journal of Marketing, 57(3), 53. https://doi.org/10.1177/002224299305700304

Jung Jung, H., Yang, H., Lee, Y., \& Kim, H. (2014). Impacts of country images on luxury fashion brand: facilitating with the brand resonance model. Journal of Fashion Marketing and Management: An International Journal, 18(2), 187-205. https://doi.org/10.1108/JFMM-10-2013-0113

Kaliappen, N., \& Hilman, H. (2017). Competitive strategies, market orientation types and innovation strategies: finding the strategic fit. World Journal of Entrepreneurship, Management and Sustainable Development, 13(3), 257-261. https://doi.org/10.1108/WJEMSD-11-2016-0048

Kantabutra, S., \& Avery, G. C. (2010). The power of vision: statements that resonate. Journal of Business Strategy, 31(1), 37-45. https://doi.org/10.1108/02756661011012769

Kocak, A., Carsrud, A., \& Oflazoglu, S. (2017). Market, entrepreneurial, and technology orientations: impact on innovation and firm performance. Management Decision, 55(2), 248-270. https://doi.org/10.1108/MD-04-2015-0146

Kohli, A. K., \& Jaworski, B. J. (1990). Market orientation: the construct, research propositions and managerial Implications, Journal of Marketing, 54(2), 1. https://doi.org/10.2307/1251866

Kohli, A. K., \& Jaworski, B. J. (1990). Market orientation: the construct, research propositions, and managerial implications. The Journal of Marketing, 1-18. https://doi.org/10.1177/002224299005400201

Kohli, A. K., Jaworski, B. J., \& Kumar, A. (1993). MARKOR: A measure of market orientation. JMR, Journal of Marketing Research, 30(4), 467. https://doi.org/10.1177/002224379303000406

Kopp, S. (2010). Social resonance and embodied coordination in face-to-face conversation with artificial interlocutors. Speech Communication, 52(6), 587-597.

https://doi.org/10.1016/j.specom.2010.02.007

Kristina, H., \& Tore, S. (2015). Customer-dominant logic: foundations and implications. Journal of Services Marketing, 29(6/7), 472-484. https://doi.org/10.1108/JSM-02-2015-0096

Kroehne, U., Funke, F., \& Steyer, R. (2003). (Why) Should we use SEM? - Pros and cons of structural equation modelling. MPR-online, 8.

Langerak, F., Hultink, E. J., \& Robben, H. S. (2004). The impact of market orientation, product advantage, and launch proficiency on new product performance and organizational performance. Journal of Product Innovation Management, 21(2), 79-94. https://doi.org/10.1111/j.0737-6782.2004.00059.x

Le, Y., Ye, F., Sheu, C., \& Yang, Q. (2018). Linking green market orientation and performance: Antecedents and processes. Journal of Cleaner Production, 192, 924-931. https://doi.org/10.1016/j.jclepro.2018.05.052

Lee, Y.-K., Kim, S.-H., Seo, M.-K., \& Hight, S. K. (2015). Market orientation and business performance: Evidence from fran- 
chising industry. International Journal of Hospitality Management, 44, 28-37. https://doi.org/10.1016/j.ijhm.2014.09.008

Lee, Y., \& Colarelli O'Connor, G. (2003). The impact of communication strategy on launching new products: The moderating role of product innovativeness. Journal of Product Innovation Management, 20(1), 4-21.

https://doi.org/10.1111/1540-5885.t01-1-201002

Li, H., \& Atuahene-Gima, K. (2001). Product innovation strategy and the performance of new technology ventures in China. Academy of Management Journal, 44(6), 1123-1134. https://doi.org/10.2307/3069392

Long, Z., Ali, K., John, E. S., \& Alma, M.-W. (2017). Exploring market orientation among Chinese small and medium-sized enterprises. Chinese Management Studies, 11(4), 617-636. https://doi.org/10.1108/CMS-08-2016-0158

Low, D. R., Chapman, R. L., \& Sloan, T. R. (2007). Inter-relationships between innovation and market orientation in SMEs. Management Research News, 30(12), 878-891. https://doi.org/10.1108/01409170710833321

Mahrous, A. A., \& Genedy, M. A. (2019). Connecting the dots. Journal of Entrepreneurship in Emerging Economies, 11(1), 2-21. https://doi.org/10.1108/JEEE-09-2016-0036

Mandhachitara, R., \& Allapach, S. (2017). Small business performance in Thailand: key success factors. Journal of Research in Marketing and Entrepreneurship, 19(2), 161-181. https://doi.org/10.1108/JRME-06-2016-0018

McNally, R. C., Cavusgil, E., \& Calantone, R. J. (2010). Product innovativeness dimensions and their relationships with product advantage, product financial performance, and project protocol. Journal of Product Innovation Management, 27(7), 991-1006. https://doi.org/10.1111/j.1540-5885.2010.00766.x

Narver, J. C., \& Slater, S. F. (1990). The effect of a market orientation on business profitability. The Journal of Marketing, 54(4), 20-35. https://doi.org/10.1177/002224299005400403

Ngek Neneh, B. (2016). Market orientation and performance: the contingency role of external environment. Environmental Economics, 7(2), 130-137. https://doi.org/10.21511/ee.07(2).2016.14

O'Cass, A., \& Sok, P. (2013). The role of intellectual resources, product innovation capability, reputational resources and marketing capability combinations in firm growth. International Small Business Journal, 32(8), 996-1018. https://doi.org/10.1177/0266242613480225

OECD. (2018). SME and Entrepreneurship Policy in Indonesia 2018.

Prifti, R., \& Alimehmeti, G. (2017). Market orientation, innovation, and firm performance - an analysis of Albanian firms. Journal of Innovation and Entrepreneurship, 6(1), 1-19. https://doi.org/10.1186/s13731-017-0069-9

Ramkumar, B. (2016). The effect of trust, transaction utility, and product uniqueness on international online outshopping (IOO) intention and customer delight: the role of e-tailer's country image $(\mathrm{PhD})$. The University of North Carolina at Greensboro. https://doi.org/10.31274/itaa_proceedings-180814-1808

Sahibzada Jawad, S. U. R., Naushad, S., Yousaf, S., \& Yousaf, Z. (2019). Exploring performance of software houses. World Journal of Entrepreneurship, Management and Sustainable Development, 16(1), 1-11.

https://doi.org/10.1108/WJEMSD-05-2019-0033
Samson, D., Gloet, M., \& Singh, P. (2017). Systematic innovation capability: evidence from case studies and a large survey. International Journal of Innovation Management, 21(07), 1750058. https://doi.org/10.1142/S136391961750058X

Setiawan, A. I., \& Hanfan, A. (2017). Elaborating the role of network synergy capacity as a supplier's alternative terminal for achieving marketing performance. International Journal of Business and Society, 18(2), 245-262. https://doi.org/10.33736/ijbs.481.2017

Shang, S. S. C., Wu, Y.-L., \& Sie, Y.-J. (2017). Generating consumer resonance for purchase intention on social network sites. Computers in Human Behavior, 69, 18-28. https://doi.org/10.1016/j.chb.2016.12.014

Sharma, A., \& Jasrotia, V. (2016). Managing customers brand experience for creating brand resonance in smartphones. International Journal on Customer Relations, 4(1), 12-23. https://doi.org/10.21863/ijcr/2016.4.1.014

Sok, P., \& O'Cass, A. (2015). Examining the new product innovation - performance relationship: Optimizing the role of individual-level creativity and attention-to-detail. Industrial Marketing Management, 47, 156-165. https://doi.org/10.1016/j.indmarman.2015.02.040

Suarez, M., \& Belk, R. (2017). Cultural resonance of global brands in Brazilian social movements. International Marketing Review, 34(4), 480-497. https://doi.org/10.1108/IMR-07-2014-0252

Sugiyarti, G., Ferdinand, A. T., \& Nurchayati, T. (2018). Acculturative products uniqueness antecedence for successful marketing performance. DLSU Business \& Economics Review, 28(1), 11.

Sullaida, Nurmala, \& Ahyar, C. (2018). The development of an independent entrepreneurship model through creative economy for women in Lhokseumawe city. In Proceedings of MICoMS 2017 (pp. 87-92).

https://doi.org/10.1108/978-1-78756-793-1-00041

Sun, J., Yao, M., Zhang, W., Chen, Y., \& Liu, Y. (2016). Entrepreneurial environment, market-oriented strategy, and entrepreneurial performance: A study of Chinese automobile firms. Internet Research, 26(2), 546-562. https://doi.org/10.1108/IntR-05-2015-0138

Tabachnick, B. G., \& Fidell, L. S. (2012). Using multivariate statistics (6th ed.). Pearson.

Watanabe, C., Kanno, G., \& Tou, Y. (2012). Inside the learning dynamism inducing the resonance between innovation and high-demand consumption: A case of Japan's high-functional mobile phones. Technological Forecasting and Social Change, 79(7), 1292-1311. https://doi.org/10.1016/j.techfore.2012.03.003

Yadav, S. K., Tripathi, V., \& Goel, G. (2019). Modelling strategic orientation dimensions and performance of small and medium enterprises. Journal of Modelling in Management, 14(3), 754-772. https://doi.org/10.1108/JM2-08-2018-0116

Zhang, J., \& Duan, Y. (2010). The impact of different types of market orientation on product innovation performance: evidence from Chinese manufacturers. Management Decision, 48(6), 849-867. https://doi.org/10.1108/00251741011053433

Zhou, K. Z., Yim, C. K., \& Tse, D. K. (2005). The effects of strategic orientations on technology-and market-based breakthrough innovations. Journal of Marketing, 69(2), 42-60. https://doi.org/10.1509/jmkg.69.2.42.60756 